\title{
Democratic Leadership and Its Impact on Teacher Performance
}

\author{
Sumardin Raupu', Deswita Maharani², Hilal Mahmud3, Alauddin4 \\ DOI: $10.35445 /$ alishlah.v13i3.990
}

\begin{tabular}{l}
\hline Article Info \\
\hline Keywords: \\
Democratic Leadership; \\
Principals; \\
Teacher Performance
\end{tabular}

\begin{abstract}
This study looks into the impact of the principal's democratic leadership style on teacher performance in junior high schools in Palopo City's Bara District. This study uses a quantitative approach with the type of research is ex-post facto. The population is all junior high school teachers in the Bara sub-district of Palopo city, totaling 134 people. Sampling was done by simple random sampling technique. The sample used was 39 teachers-data obtained through questionnaires and documentation. Furthermore, the research data were analyzed statistically using data processing, namely: Descriptive statistical analysis and inferential statistical analysis. This study found that the democratic leadership style displayed by the principal has a strong influence and significance on the performance of teachers in SMP/MTs in Bara District, Palopo City. This is because the leadership style displayed by the principal through several indicators can provide a significant enough stimulant to the teacher so that teachers' work motivation can increase adequately, which impacts the achievement of educational and learning goals in schools. This study implies the importance of the leadership style displayed by the principal in building teacher motivation and commitment in schools to generate optimal teacher performance in schools.
\end{abstract}

Kata kunci:

Kepemimpinan

Demokratis;

Kepala Sekolah;

Kinerja Guru

\begin{abstract}
Abstrak
Penelitian ini bertujuan untuk menganalisis tentang pengaruh gaya kepemimpinan demokratis kepala sekolah terhadap kinerja guru di SMP/MTs se-Kecamatan Bara Kota Palopo. Penelitian ini menggunakan pendekatan kuantitatif dengan Jenis penelitian adalah ex-post facto. Populasinya adalah seluruh guru SMP/MTs Se-Kecamatan Bara kota Palopo yang berjumlah 134 orang. Pengambilan sampel dilakukan dengan teknik simple random sampling. Sampel yang digunakan sebanyak 39 guru. Data yang diperoleh melalui angket dan dokumentasi. Selanjutnya, data penelitian dianalisis statistik menggunakan pengolahan data yaitu: Analisis statistik deskriptif dan analisis statistik inferensial. Penelitian ini menghasilkan temuan bahwa gaya kepemimpinan demokratis yang ditampilkan oleh kepala sekolah memiliki pengaruh dan signifikansi yang tinggi terhadap kinerja guru di SMP/MTs seKecamatan Bara Kota Palopo. Hal ini disebabkan karena gaya kepemimpinan yang ditampilkan oleh kepala melalui beberapa indicator mampu memberikan stimulant yang cukup besar kepada bahwannya, sehingga motivasi kerja guru dapat meningkat dengan baik, yang berdampak pada tercapainya tujuan
\end{abstract}

\footnotetext{
${ }^{1}$ IAIN Palopo, South Sulawesi, Indonesia

Email: sumardin_aldhy@iainpalopo.ac.id

${ }^{2}$ IAIN Palopo, South Sulawesi, Indonesia

Email: deswita_maharani_mhs@iainpalopo.ac.id

3 IAIN Palopo, South Sulawesi, Indonesia

Email: hilalmahmud@iainpalopo.ac.id

4 IAIN Palopo, South Sulawesi, Indonesia

Email: drs_alauddin@iainpalopo.ac.id
} 
pendidikan dan pembelajaran di sekolah. Penelitian ini memberikan implikasi tentang pentingnya gaya kepemimpinan yang ditampilkan oleh kepala sekolah dalam membangun motivasi dan komitmen guru di sekolah, sehingga mampu membangkitkan kinerja guru di sekolah secara optimal.

\section{INTRODUCTION}

Leadership can be a benchmark in the success of every activity carried out by human resources in institutions, especially educational institutions (Everett \& Raven, 2018). Principal leadership can influence activities that occur in schools (Rehman, Khan, \& Waheed, 2019; Rostiawati, 2020). Of course, principals who have managerial abilities and can accept opinions or suggestions from teachers strongly influence the success of existing education. at school (Kheruniah, 2013; Cilek, 2019).

One of the essential components to achieve national education goals is that the principal is responsible for completing the school's vision and mission (Nurdiansyah, 2021). The principal is also the driving factor behind the school's resources (Rahman \& Subiyantoro, 2021). More specifically, school principals are required to be able to move teachers effectively, foster good relations in schools to create a conducive atmosphere, create cohesiveness in schools, and carry out planning, implementation, and evaluation of various policies that have been implemented in schools (Khosiah \& Maryani, 2020; Salim \& Hasanah, 2021).

Every principal has a different leadership style. To be able to move an organization, an effective leadership style is needed by the principal. Leadership style refers to a leader's behavior or approach to influencing the organization's members' thoughts, feelings, attitudes, and behavior (Wibowo \& Hasanah, 2021). Leadership style is a complex way and process in which one person influences others to achieve a mission, task, or goal and directs the organization in a way that makes more sense. (Wirjana \& Supardo, 2011). As a result, leadership style can be defined as a person's attitude and behavior that influences others to achieve common goals.

The leadership style is meant as a typical way of behaving from a leader towards his group members (Munir \& Iqbal, 2018; Hill-Berry, 2019). Three principal leadership styles are most widely and well known: autocratic, democratic, and laissez-faire leadership styles (Usman, 2011; Hefniy et al., 2020). Hersey and Blanchard (1997) suggest that effective leadership styles vary according to the maturity of subordinates. The educational leadership style is the way a leader of an educational institution organizes, directs, and guides teachers so that they can work together to achieve academic goals (Fathorrazi, 2017; Bali et al., 2020). The principle can use a more effective or varied leadership style to ensure that the required objectives are met effectively and efficiently (Said, 2018).

Russamsi et al., (2020) research found that principal leadership could improve teacher professionalism and performance. According to Zainuddin et al. (2020), a principal's leadership combined with effective organizational communication can boost teacher commitment, enhancing performance. Endaryono et al. (2021) said that the democratic leadership style is ideal for school principals. They make decisions by deliberation by involving all elements by consensus, carry out decisions by delegating authority and responsibility to subordinates, and program evaluations are carried out systematically. Objective and continuous.

In their study, Rohman \& Muna (2019) believe that the principal's democratic leadership typology is a crucial virtue. Schools are capable of competing in educational competitions and are prepared to face any challenge. Nasir et al. (2021) added that the democratic leadership model of madrasah principals is shown by the behavior of principals who are communicative, disciplined, responsible, dare to innovate, honest, open, have good social relations with madrasa residents, and involve subordinates together. Same for making changes. According to Yanti (2021), the democratic leadership style positively and significantly affects teachers' educational, personality, professional and social competencies. 
Democratic leadership gives staff and teachers confidence in carrying out their duties, rewards teachers who make change and creativity, and provides opportunities for staff and teachers who make mistakes to improve themselves (Saputra et al., 2021). Principal democratic leadership can appear in the form of influencing teachers to want to do something together to achieve educational goals (Sanjani, 2018), where teachers will improve their performance in their respective fields (Yanti, 2021).

Employees who participate in an organization are the most critical resources in maximizing the potential of other organizational resources and improving overall performance. The appearance of personal effort in terms of quantity and quality in an organization is performing (Rahsel, 2017). According to Hasibuan (2010), performance is defined as a person's effort to carry out responsibilities based on skills, experience, sincerity, and time. There are at least three categories in this performance: ability in the workplace, ability in social situations, and ability in one's personal life (Asri, 2018). Teacher performance refers to a teacher's overall conduct in carrying out the activities that have been allocated to him as a teacher, trainer, mentor, coach, or student educator, to improve the teaching profession through mastery of these critical tasks (Rosaliawati et al., 2020)

According to Herosita's (2017) findings, the democratic leadership of the principal can increase teacher work discipline in schools. Similarly, according to Nadir (2018), the democratic administration of the principal has a substantial impact on improving the performance of teachers and school personnel. Cecilia (2020) noted that transformational, autocratic, and democratic principal leadership styles positively influence teacher performance in schools, while transactional, charismatic, and bureaucratic leadership styles hurt teacher performance. Transactional and authoritarian leadership styles have a positive and significant impact on teacher performance, according to Purwanto et al. (2020).

Nasukah et al. (2020) say that to improve the performance of teachers and staff. Good communication skills are needed from a leader. The professional allowance and education and professional training have a positive and considerable impact on teacher performance, according to Kurniawan (2018). Still, teachers need to commit to improve performance and develop themselves as professional responsibility continually. This is reinforced by Najemiah's research (2017), which states that supervision and certification simultaneously significantly affect teacher performance in schools.

Given the importance of democratic leadership and teacher performance for the sustainability of educational institutions, the researchers are interested in evaluating the democratic leadership style of school principals on boosting the performance of SMP/MTs instructors in Bara District, Palopo City. The findings of this study are intended to improve instructors' performance in educational institutions and the quality of education they provide so that they are superior and competitive in the face of rivalry among academic institutions.

\section{METHODS}

This study was conducted in SMP/MTs in Palopo City's Bara District using a quantitative technique. Ex-post-facto analysis with simple regression is research that aims to determine current problem solving based on data, present data, and analyze data.

The total number of teachers at the SMP/MT level in the Bara District of Palopo City, which is 134 people, is used in this study. The proportional random sample strategy was utilized in this investigation. The following are the specifics of the research sample: 
Table 1: Research sample

\begin{tabular}{lcc}
\multicolumn{1}{c}{ SMP/MTS School } & Sampel & Number of samples \\
\hline SMPN 5 Palopo & $30 \% \times 34=10,2$ & 10 \\
SMPN 8 Palopo & $30 \% \times 47=14,1$ & 14 \\
MTsS Datok Sulaiman Palopo & $30 \% \times 15=4,5$ & 4 \\
SMP Datok Sulaiman Palopo & $30 \% \times 38=11,4$ & 11 \\
\hline \multicolumn{1}{c}{ Amount } & & 39 \\
\hline
\end{tabular}

The researcher employed a questionnaire or a collection of statements or questions presented to respondents to collect the data and information needed for this investigation. Based on the indicators that support the research variables with the theory that has been described, it can be stated indicators of the research variables:

Table 2: Research variable indicators

\begin{tabular}{lclcc}
\hline \multirow{2}{*}{ Variable } & \multirow{2}{*}{ No } & & \multicolumn{1}{c}{ Indicator } & \multicolumn{2}{c}{ Alternative Answer } \\
\cline { 3 - 5 } & 1 & Make decisions together & $\mathbf{( + )}$ & $\mathbf{( - )}$ \\
\hline \multirow{3}{*}{ Democratic } & 2 & Emphasize a sense of responsibility & $2,12,17,21$ & $16,11,20$ \\
Leadership Style & 3 & Appreciate Master's opinion & $13,8,22$ & 18,3 \\
& 4 & Prioritize or cooperate with teachers & 4,14 & 9,19 \\
& 5 & Giving motivation & 23 & $5,10,15$ \\
\hline \multirow{4}{*}{ Performance } & 1 & Planning lessons & 1,11 & 6 \\
& 2 & Carry out learning & 7,12 & 2 \\
& 3 & Assessing learning outcomes & 3,13 & 8 \\
& 4 & Guiding and training students & $14,9,4$ & 16 \\
& 5 & Carry out additional tasks & 10,17 & 5,15 \\
\hline
\end{tabular}

The researcher used a Likert scale on each variable in this case, with strong agree (SS), agree (S), disagree (KS), and disagree (KS) as the options (TS). The weighting starts at 4, 3, 2, 1 and goes up from there. Following the collection of data, the data processing and analysis stage is completed. SPSS software for Windows version 20 was used to analyze the data used in this study.

The data analysis technique of this research uses;

1) Descriptive Statistical Analysis

The data collected using this questionnaire was measured using a Likert scale. After the data obtained in this study is considered sufficient, the writing of its management uses descriptive analysis methods. Using descriptive statistical analysis, the value gained from the questionnaire findings on the influence of the principal's democratic leadership style on the performance of SMP/MTs teachers in Bara District, Palopo City, was described. With the need for this analysis, it is used to describe the characteristics of the respondent's value in the form of average, median, the standard deviation of variation, about the score, lowest value and highest value, and frequency distribution table histogram.

Furthermore, Suherman (2014)classified the characteristics that impact the principal's democratic leadership style and teacher performance as follows:

Table 3: Categorization of Principal Democratic Leadership Styles and Teacher Performance

\begin{tabular}{cc}
\hline Score (\%) & Category \\
\hline $0 \%-34 \%$ & Very low \\
$35 \%-54 \%$ & low \\
$55 \%-64 \%$ & Currently \\
$65 \%-84 \%$ & Tall \\
$85 \%-100 \%$ & Very high \\
\hline
\end{tabular}


2) Inferential statistical analysis

a. Normality test

The purpose of the data normality test is to determine whether the data from the study findings are typically distributed. The normality test was carried out in this study using the IMB SPSS application. The basis for making decisions meets normality and does not: The data is usually distributed if the significance value is $>a(0.05)$. Meanwhile, if the significance value is less than 0.05 , the data is not regularly distributed.

b. Heteroscedasticity Test

The heteroscedasticity test determines whether or not the variances of the variables in the regression model are equal. On the other hand, homoscedasticity is the variance of the variables in the regression model having the same value (constant). Because this data includes data reflecting diverse sizes, a reasonable regression model is homoscedasticity, or there is no heteroscedasticity (small, medium, and large). In this work, we used simple linear regression analysis and, if $\mathrm{T}_{\text {count }} \mathrm{T}_{\text {table, }}$, then $\mathrm{H}_{\mathrm{o}}$ is rejected and $\mathrm{H}_{1}$ is accepted. If $\mathrm{T}_{\text {count }} \mathrm{T}_{\text {table }}$ then Ho is accepted, $\mathrm{H}_{1}$ is denied. Based on the probability, if significant $\mathrm{T}$ (probability) is 0.05 , then $\mathrm{H} 1$ is rejected; if significant $\mathrm{T}$ (probability) is $0.05, \mathrm{H}_{0}$ is accepted.

\section{FINDINGS AND DISCUSSIONS}

\section{Instrument validity}

Before the questionnaire was used, the researcher conducted a content validity test by selecting three expert validators who had competence in education to fill out the validation format. In content validity, Aiken's formula is used while the results of the truth of the three expert validators are as follows:

Table 4: The results of the validity of the questionnaire data for research on the democratic leadership style of school principals

\begin{tabular}{|c|c|c|c|c|c|c|c|c|c|c|c|c|}
\hline Validator & \multicolumn{2}{|c|}{ Item 1} & \multicolumn{2}{|c|}{ Item 2} & \multicolumn{2}{|c|}{ Item 3} & \multicolumn{2}{|c|}{ Item 4} & \multicolumn{2}{|c|}{ Item 5} & \multicolumn{2}{|c|}{ Item 6} \\
\hline & Score & $\mathrm{S}$ & Score & $\mathbf{S}$ & Score & $\mathbf{S}$ & Score & $\mathbf{S}$ & Score & $\mathbf{S}$ & Score & $\overline{\mathbf{S}}$ \\
\hline Validator 1 & 4 & 3 & 3 & 2 & 4 & 3 & 3 & 2 & 4 & 3 & 3 & 2 \\
\hline Validator 2 & 3 & 2 & 3 & 2 & 3 & 2 & 3 & 2 & 3 & 2 & 4 & 3 \\
\hline Validator 3 & 3 & 2 & 3 & 2 & 3 & 2 & 3 & 2 & 3 & 2 & 3 & 2 \\
\hline$\sum \mathrm{s}$ & 7 & & 6 & & 7 & & 6 & & 7 & & 7 & \\
\hline V & 0.77 & & 1.00 & & 0.77 & & 1.00 & & 0.77 & & 0.77 & \\
\hline
\end{tabular}

Based on the table above, the average value of V (Aiken's) is 0.846. Furthermore, it will be compared using the interpretation that can be seen in the table below:

Table 5: Interpretation of Content Validity

\begin{tabular}{cc}
\hline Interval & Interpretation \\
\hline $0,00-0,199$ & Very Invalid \\
$0,20-0,399$ & Invalid \\
$0,40-0,599$ & Less Valid \\
$0,60-0,799$ & Valid \\
$0,80-1,00$ & Very Valid \\
\hline
\end{tabular}

The average value of $\mathrm{V}$ (Aiken's) of the content validity of the principal's democratic leadership style can be stated to be adequate based on the table above (very valid).

Table 6: Results of Questionnaire Data Validity for Teacher Performance

\begin{tabular}{ccccccccccccc}
\hline Validator & Item 1 & \multicolumn{1}{c}{ Item 2 } & \multicolumn{2}{c}{ Item 3 } & \multicolumn{2}{c}{ Item 4 } & \multicolumn{2}{c}{ Item 5 } & \multicolumn{2}{c}{ Item 6 } \\
\hline & Score & S & Score & S & Score & S & Score & S & Score & S & Score & S \\
Validator 1 & 4 & 3 & 3 & 2 & 4 & 3 & 3 & 2 & 4 & 3 & 3 & 2 \\
Validator 2 & 3 & 2 & 3 & 2 & 3 & 2 & 3 & 2 & 3 & 2 & 3 & 2 \\
Validator 3 & 3 & 2 & 3 & 2 & 3 & 2 & 3 & 2 & 3 & 2 & 3 & 2 \\
$\sum$ S & 7 & & 6 & & 7 & & 6 & & 7 & & 6 & \\
V & 0.77 & & 1.00 & & 0.77 & 1.00 & 0.77 & 0.77 \\
\hline
\end{tabular}


The average value of $\mathrm{V}$ (Aiken's) is 0.846 , according to the table above. It will also be compared using the interpretation shown in table 4.7. It can be determined that the average value of V (Aiken's) of the content validity of Teacher Performance is appropriate (very valid).

\section{Instrument Reliability}

The table below shows the results of the reliability testing:

Table 7: Principal's Democratic Leadership Style Reliability Test Reliability Statistics Cronbach's Alpha $\quad \mathrm{N}$ of Items

.599

Based on table 7 above, the reliability test was obtained for the Principal Democratic Leadership Style questionnaire with an $r_{11}$ value of 0.599 or 0.60. Thus, the Principal Democratic Leadership Style questionnaire has high-reliability criteria based on the reliability table.

Table 8: Reliability Test of Teacher Performance Reliability Statistics Cronbach's Alpha $\mathrm{N}$ of Items

.490

Then for table 8, the reliability test for teacher performance questionnaires obtained an r11 value of 0.490 . Thus, based on the reliability interpretation table, the teacher performance questionnaire has sufficient criteria.

\section{Descriptive Statistical Analysis Results}

Data is organized, presented, and analyzed using descriptive statistical analysis. Statistical approaches, such as creating a frequency distribution table, can be used to describe the data. The mean, minimum, maximum, variance, standard deviation, frequency distribution table, and other calculations are used in descriptive statistical analysis to describe the characteristics of respondents. 1) Principal's Democratic Leadership Style

According to descriptive statistical analysis, the mean score was 64.59 , with a variance of 21,410 and a standard deviation of 4.627 from the lowest score of 57 to the highest score of 78 for the principal democratic leadership style variable (X) provided an overview of the distribution characteristics of the mean score of 64.59 and variance of 21,410 with a standard deviation of 4.627 from the lowest score of 57 to the highest score of 78 for the Principal Democratic Leadership Style variable (X). Table 9 illustrates this point;

Table 9: Descriptive Statistical Test Results of Principal's Democratic Leadership Style

\begin{tabular}{lrrrrrr}
\hline & N & Minimum & Maximum & Mean & Std. Deviation & Variance \\
\hline $\begin{array}{l}\text { Principal democratic leadership } \\
\text { style }\end{array}$ & 39 & 57 & 78 & 64.56 & 4.627 & 21.410 \\
Valid N (listwise) & 39 & & & & & \\
\hline
\end{tabular}

A table showing the frequency distribution and percentage of the principal's leadership style may be obtained by grouping the Principal's Democratic Leadership Style scores into five categorizations. The following is the frequency distribution table and a piece of the Principal's Democratic Leadership Style:

Table 10: Percentage Gaining Categorization of Principal's Democratic Leadership Style

\begin{tabular}{cccc}
\hline Score & Categorization & Frequency & Percentage (\%) \\
\hline $55-60$ & Very low & 8 & $20 \%$ \\
$61-65$ & Low & 3 & $8 \%$ \\
$66-70$ & Currently & 11 & $28 \%$ \\
$71-75$ & Tall & 16 & $41 \%$ \\
$76-80$ & Very high & 1 & $3 \%$ \\
\hline & Amount & 39 & $100 \%$ \\
\hline
\end{tabular}


In general, principals of SMP/MTs in Bara District, Palopo City have a Democratic Leadership Style with a Very Low category, namely with a percentage of $20 \%$ because they have a sampling frequency of 8 , for the Low category, a percentage of $8 \%$ is obtained. After all, they have a sampling frequency of 3 people. At the same time, the Medium category received a percentage of $28 \%$, with a sampling frequency of 11 people, for the High category it had a percentage of $41 \%$, with a sampling frequency of 16 people, and the Very High category had a percentage of $3 \%$, with a sampling frequency of 1 person.

The democratic leadership style of principals of SMP/MTs in Bara District, Palopo City, is included in the high classification with a sampling frequency of 16 persons, according to tables 9 and 10 , and the percentage result is $41 \%$ with a mean score of 64.56 . The respondents' responses to the questionnaire have a significant impact on the principal's democratic leadership style. In the Bara District of Palopo City, the rate reached was $41 \%$ of all SMP/MTs schools.

There are 4 SMP/MTs in Bara District, Palopo City, so the researcher will see the percentage of Democratic leadership style on teacher performance from each school by using descriptive statistical test results analysis.

a) SMPN 5 Palopo

Table 11: Descriptive Statistical Test Results of the Principal's Democratic Leadership Style of SMPN 5 Palopo

\begin{tabular}{lccccc}
\hline & $\mathrm{N}$ & Minimum & Maximum & Mean & Std. Deviation \\
\hline $\begin{array}{l}\text { The Democratic Leadership Style of the } \\
\text { Principal of SMPN 5 Palopo }\end{array}$ & 10 & 59 & 71 & 64.40 & 3.950 \\
\hline Valid N (listwise) & 10 & & & & \\
\hline
\end{tabular}

The results of descriptive statistical analysis related to the score of the Principal Democratic Leadership Style variable at SMPN 5 obtained a characteristic picture of the distribution of the mean score, which is 64.40 with a standard deviation of 3.950 from the lowest score of 59 and the highest score of 71. If the Principal's Democratic Leadership Style score is grouped into five categorizations, the frequency distribution table and percentage of the Principal's Democratic Leadership Style of SMPN 5 are obtained as follows:

Table 12: Percentage Gaining Categorization of Democratic Leadership Style Principals of SMPN 5

\begin{tabular}{cccc}
\hline Score & Categorization & Frequency & Percentage (\%) \\
\hline $31-40$ & Very low & 0 & $0 \%$ \\
$41-50$ & Low & 0 & $0 \%$ \\
$51-60$ & Currently & 1 & $10 \%$ \\
$61-70$ & Tall & 7 & $70 \%$ \\
$71-80$ & Very high & 2 & $20 \%$ \\
& Amount & 10 & $100 \%$ \\
\hline
\end{tabular}

Based on tables 11 and 12, it can be concluded that the Principal's Democratic Leadership Style at SMPN 5 Palopo is included in the high categorization with a sampling frequency of 7 people, and the percentage result is $70 \%$ with a mean score of 64.40 .

b) SMPN 8 Palopo

Table 13: Descriptive Statistical Test Results of the Principal's Democratic Leadership Style of SMPN 8 Palopo

\begin{tabular}{lccccc}
\hline & $\mathrm{N}$ & Minimum & Maximum & Mean & Std. Deviation \\
\hline $\begin{array}{l}\text { Democratic leadership style of the } \\
\text { principal of SMPN 8 Palopo }\end{array}$ & 14 & 57 & 78 & 67.21 & 5.026 \\
\hline Valid N (listwise) & 14 & & & & \\
\hline
\end{tabular}

The results of descriptive statistical analysis related to the score of the Principal Democratic Leadership Style variable at SMPN 8 Palopo obtained a characteristic picture of the distribution of 
the mean score, which is 67.21 with a standard deviation of 5,026 from the lowest score of 57 and the highest score of 78. Suppose the score of the Principal's Democratic Leadership Style is grouped into five categorizations. In that case, the frequency distribution table and percentage of the Principal's Democratic Leadership Style of SMPN 8 Palopo are obtained as follows:

Table 14: Percentage Gain of Democratic Leadership Style Categorization at SMPN 8 Palopo

\begin{tabular}{cccc}
\hline Score & Categorization & Frequency & Percentage (\%) \\
\hline $31-40$ & Very low & 0 & $0 \%$ \\
$41-50$ & Low & 0 & $0 \%$ \\
$51-60$ & Currently & 1 & $7 \%$ \\
$61-70$ & Tall & 11 & $79 \%$ \\
$71-80$ & Very high & 2 & $14 \%$ \\
& Amount & 14 & $100 \%$ \\
\hline
\end{tabular}

The democratic leadership style of the principal of SMPN 8 Palopo is included in the high categorization with a sampling frequency of 11 persons, a percentage of 79 percent, and a mean score of 67.21, as shown in tables 13 and 14.

c) SMP Datok Sulaiman Palopo

Table 15: Descriptive Statistical Test Results of Principal's Democratic Leadership Style at SMP Datok Sulaiman Palopo

\begin{tabular}{llcccc}
\hline & $\mathrm{N}$ & $\begin{array}{c}\text { Minimu } \\
\mathrm{m}\end{array}$ & $\begin{array}{c}\text { Maximu } \\
\mathrm{m}\end{array}$ & Mean & Std. Deviation \\
\hline $\begin{array}{l}\text { democratic leadership style of the principal of } \\
\text { SMP Datok Sulaiman Palopo }\end{array}$ & 11 & 58 & 70 & 61.91 & 3.590 \\
\hline Valid N (listwise) & 11 & & & & \\
\hline
\end{tabular}

The descriptive statistical analysis results related to the variable score of the principal democratic SMP Datok Sulaiman Palopo leadership style from the lowest score of 58 to the highest score of 70, acquired a description of the distribution characteristics with a mean score of 61.91 and a standard deviation of 3,590. Suppose the score of the Principal's Democratic Leadership Style is grouped into From five categorizations. In that case, the frequency distribution table and percentage of the Democratic Leadership Style of the Principal of SMP Datok Sulaiman Palopo are obtained as follows:

Table 16: Acquired Percentage of Democratic Leadership Style Categorization Principal of SMP Datok Sulaiman Palopo

\begin{tabular}{cccc}
\hline Score & Categorization & Frequency & Percentage (\%) \\
\hline $46-40$ & Very low & 0 & $0 \%$ \\
$51-55$ & Low & 0 & $0 \%$ \\
$56-60$ & Currently & 5 & $45 \%$ \\
$61-65$ & Tall & 5 & $45 \%$ \\
$66-70$ & Very high & 1 & $10 \%$ \\
\hline & Amount & 11 & $100 \%$ \\
\hline
\end{tabular}

With a sampling frequency of 5 persons and a percentage result of 45 percent and a mean score of 61.91, it can be inferred that the Democratic Leadership Style of SMP Principal Datok Sulaiman Palopo is included in the High classification.

d) MTsS Datok Sulaiman Palopo

Table 17: Descriptive Statistical Test Results for the Democratic Leadership Style of MTsS Principal Datok Sulaiman Palopo

\begin{tabular}{lccccc}
\hline & $\mathrm{N}$ & $\begin{array}{c}\text { Minimu } \\
\mathrm{m}\end{array}$ & $\begin{array}{c}\text { Maximu } \\
\mathrm{m}\end{array}$ & Mean & Std. Deviation \\
\hline $\begin{array}{l}\text { the democratic leadership style of the } \\
\text { principal of MTsS Datok Sulaiman Palopo }\end{array}$ & 4 & 60 & 67 & 63.00 & 3.162 \\
\hline Valid N (listwise) & 4 & & & & \\
\hline
\end{tabular}


The results of descriptive statistical analysis related to the variable score of the Principal's Democratic Leadership Style at MTsS Datok Sulaiman Palopo obtained a description of the characteristics of the distribution of the mean score of 63.00 with a standard deviation of 3.162 from the lowest score of 60 and the highest score of 67. Suppose the scores of the Principal's Democratic Leadership Style are grouped into five categorizations. In that case, the frequency distribution table and percentage of the Democratic Leadership Style of MTsS Principal Datok Sulaiman Palopo are obtained as follows:

Table 18: Percentage Gaining Categorization of Democratic Leadership Style MTsS Principal Datok Sulaiman Palopo

\begin{tabular}{cccc}
\hline Score & Categorization & Frequency & Percentage (\%) \\
\hline $46-40$ & Very low & 0 & $0 \%$ \\
$51-55$ & Low & 0 & $0 \%$ \\
$56-60$ & Currently & 0 & $0 \%$ \\
$61-65$ & Tall & 3 & $75 \%$ \\
$66-70$ & Very high & 1 & $25 \%$ \\
\hline & Amount & 4 & $100 \%$ \\
\hline
\end{tabular}

Tables 17 and 18 show that MTsS Principal Datok Sulaiman Palopo's Democratic Leadership Style falls into the high categorization category, with a sampling frequency of three people, a percentage of 75 percent, and a mean score of 63.00.

The principal's democratic leadership style percentage was determined using descriptive statistical tests done in part for each SMP / MTs in Bara District, Palopo City. It can be concluded that SMPN 5 Palopo has a rate of 70\%, SMPN 8 Palopo has a rate of 79 percent, and SMP Datok has a rate of 45 percent. MTsS Datok Sulaiman Palopo accounts for $75 \%$ of the total. The descriptive statistical analysis of the democratic leadership style of the four schools' highest principal, SMPN 8 Palopo, can be seen. The distribution of the mean score of 67.21 is included in the high categorization with a sampling frequency of 11 people, yielding a percentage result of 79 percent.

2) Teacher Performance

The findings of descriptive statistical analysis of the Teacher Performance variable (Y) score yielded a description of the distribution features of the mean score, which is 49.36 , and the variance, which is 11.184 , with a standard deviation of 3.344 , ranging from 41 to 59 . This is illustrated in Table 19:

Table 19: Descriptive Statistics Test Results of Teacher Performance

\begin{tabular}{lcccccc}
\hline & $\mathrm{N}$ & Minimum & Maximum & Mean & Std. Deviation & Variance \\
\hline Teacher Performance & 39 & 41 & 59 & 49.36 & 3.344 & 11.184 \\
Valid N (listwise) & 39 & & & & & \\
\hline
\end{tabular}

If the teacher's performance scores are grouped into five categories, a table of the frequency distribution and percentage of teacher performance is obtained. The following is the frequency distribution chart and percentage of Teacher Performance:

Table 20: Gained Percentage of Teacher Performance Categorization

\begin{tabular}{|c|c|c|c|}
\hline Score & Categorization & Frequency & Percentage (\%) \\
\hline $35-49$ & Very low & 0 & $0 \%$ \\
\hline $41-45$ & Low & 2 & $5 \%$ \\
\hline $46-50$ & Currently & 22 & $56 \%$ \\
\hline $51-55$ & Tall & 7 & $18 \%$ \\
\hline $56-60$ & Very high & 8 & $21 \%$ \\
\hline \multicolumn{2}{|c|}{ Amount } & 39 & $100 \%$ \\
\hline
\end{tabular}


According to the table above, the results of the questionnaire on the Teacher Performance variable (Y) acquired from the research sample reveal that; In general, the performance of SMP/MTs teachers in Bara District, Palopo City who have deficient performance is obtained by a percentage of $0 \%$ because they have a sampling frequency of o, for the Low category a percentage of $5 \%$ is obtained. After all, they have a sampling frequency of 2. At the same time, the Medium category gets a percentage of $56 \%$ with a frequency of a sample of 22 people, for the High category has a percentage of $18 \%$ with a sampling frequency of 7 people. The outstanding category as a percentage of $21 \%$, with a sampling frequency of 8 people.

With a sampling frequency of 22 people, it can be stated that the teacher performance of SMP/MTs in Bara District, Palopo City falls into the Medium category, as shown in tables 19 and 20. Moreover, the percentage result is $56 \%$, with a mean score of 49.36 . The high percentage of teacher performance results is influenced by the respondents' answers to the questionnaire given.

\section{Classic Assumption Test}

1) Data Normality Test

Table 21: One-Sample Kolmogorov-Smirnov Test

\begin{tabular}{llr}
\hline & & Unstandardized Residual \\
\hline $\mathrm{N}$ & & 39 \\
Normal Parameters(a,b) & Mean & .0000000 \\
& Std. Deviation & 1.76891403 \\
Most Extreme Differences & Absolute & .166 \\
& Positive & .166 \\
& Negative & -.100 \\
Kolmogorov-Smirnov Z & & 1.036 \\
Asymp. Sig. (2-tailed) & & .233 \\
\hline
\end{tabular}

a Test distribution is Normal.

b Calculated from data.

A significant value of 0.233 was obtained from the data normality test findings obtained using the One-Sample Kolmogorov-Smirnov Test. The critical matter is more important than the probability value $(0.233>0.05)$ than 0.05 . It can be determined that the data under investigation is typically dispersed.

2) Heteroscedasticity Test

Tabel 22: Heteroscedasticity Test Results

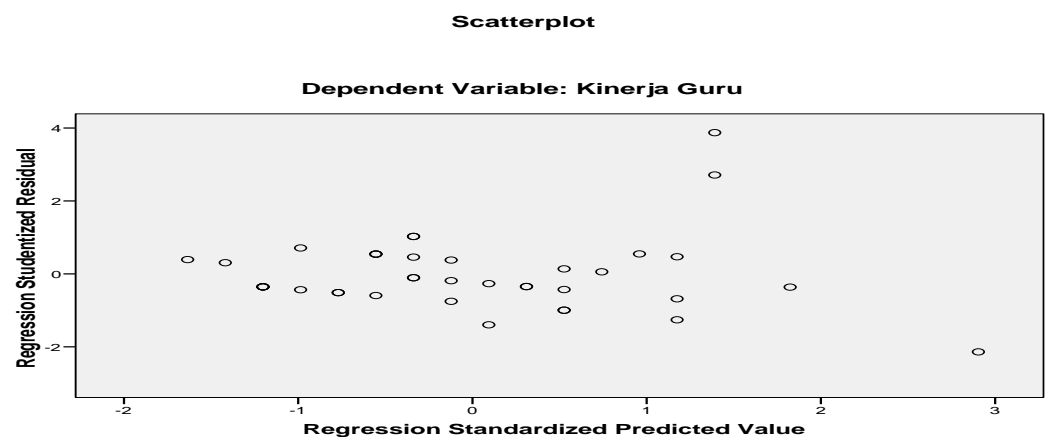

Based on the scatterplot output above, it can be seen that:

a. The dots don't collect just above or below

b. Spreader data points above, below, or in the vicinity of o

c. There is no pattern in the distribution of data points.

d. The data point spread does not form an expanding pattern but instead narrows and widens again. 
As a result, there is no problem with heteroscedasticity, allowing for building an effective regression model.

\section{Simple Regression Analysis}

Tabel 23: Coefficients (a)

\begin{tabular}{llccccc}
\hline Model & & \multicolumn{2}{c}{$\begin{array}{c}\text { Unstandardized } \\
\text { Coefficients }\end{array}$} & $\begin{array}{c}\text { Standardized } \\
\text { Coefficients }\end{array}$ & T & Sig. \\
\hline \multirow{4}{*}{1} & & B & Std. Error & Beta & B & Std. Error \\
& & 42.207 & 4.068 & & 10.376 & .000 \\
& (Constant) & .143 & .063 & .349 & 2.268 & .029 \\
& Democratic Leadership & .068 & & & \\
\hline
\end{tabular}

Dependent Variable: Teacher Performance

Based on the table above, it can be interpreted as follows;

1. A constant of positive 42,207; means that if the democratic leadership style (X) is $\mathrm{O}$, then the teacher's performance $(\mathrm{Y})$ is positive, which is 42,207

2. The regression coefficient of the democratic leadership style variable $(\mathrm{X})$ is positive 0.143 ; The teacher's performance (Y) will improve by 0.143 if the democratic leadership style (X) increases by one. The positive coefficient indicates that democratic leadership style and teacher performance have a good association.

a. Research Hypothesis Test

1. Coefficient of Determination $\mathrm{R}^{2}$

Tabel 24: Coefficient of Determination

\begin{tabular}{lllll}
\hline Model & R & R Square & Adjusted R Square & Std. Error of the Estimate
\end{tabular}

\begin{tabular}{lllll}
\hline 1 & $.349(\mathrm{a})$ & .122 & .098 & 1.793 \\
\hline
\end{tabular}

a Predictors: (Constant), Democratic Leadership Style

b Dependent Variable: Teacher Performance

According to the coefficient of determination ( $\mathrm{R}$ Square) results, the coefficient of determination ( $\mathrm{R}$ Square) value is 0.122. The coefficient of determination ( $\mathrm{R}$ Square) has a magnitude of 0.122 or 12.2 percent. This result indicates that democratic leadership has a 12.2 percent impact on teacher performance. The remainder (100 percent -12.2 percent $=87.8 \%$ ) is impacted by variables not included in this regression model. Error is a term used to describe the extent of the influence of other factors (e). Other factors that are influenced outside the variables of democratic leadership style and teacher performance are not examined by the researchers themselves, such as salary, working environment conditions, rank, responsibility and work performance, and so on at school.

2. Test (t-test)

Tabel 25: Test Results (T)

Coefficients(a)

\begin{tabular}{|c|c|c|c|c|c|c|}
\hline \multirow[t]{2}{*}{ Model } & & \multicolumn{2}{|c|}{$\begin{array}{c}\text { Unstandardized } \\
\text { Coefficients }\end{array}$} & $\begin{array}{c}\text { Standardized } \\
\text { Coefficients }\end{array}$ & $\mathrm{T}$ & Sig. \\
\hline & & $\mathrm{B}$ & $\begin{array}{c}\text { Std. } \\
\text { Error }\end{array}$ & Beta & B & $\begin{array}{l}\text { Std. } \\
\text { Error }\end{array}$ \\
\hline \multirow[t]{2}{*}{1} & (Constant) & 42.207 & 4.068 & & 10.376 & .000 \\
\hline & Democratic Leadership Style & 143 & .063 & .349 & 2.268 & .029 \\
\hline
\end{tabular}

a Dependent Variable: Teacher Performance 
The independent variable has a significant effect on the dependent variable, according to the findings of the test (t-test), when evaluated from the value of $t_{\text {count }}>t_{\text {table }}$ and significant value 0.05 ( $\mathrm{H}_{\mathrm{o}}$ is rejected and $\mathrm{H}_{1}$ is accepted). The Coefficients output produced a Tcount value of 2.268 and a

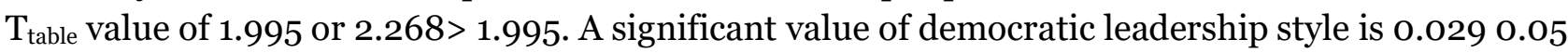
$\left(\mathrm{H}_{\mathrm{o}}\right.$ is rejected and $\mathrm{H}_{1}$ is accepted), implying that democratic leadership style significantly impacts teacher performance.

The findings of this study support Kholil \& Karwanto's (2021) research, which claims that school principals frequently use a democratic leadership style in managing schools to increase teacher performance. This is because democratic leadership is free and protects all school subordinates, especially teachers, in improving their performance. Leadership, which can be demonstrated in how someone leads his subordinates, is one of the factors that can increase teacher effectiveness. According to (2016), the principal's leadership style considerably impacts teacher performance. Teacher performance refers to a teacher's overall conduct in carrying out the activities allocated to him as a teacher, trainer, mentor, coach, or student educator, to improve the teaching profession through mastery of these critical tasks.

Democratic principal leadership, as stated by Ghozali \& Milansari (2015) that this democratic style or type of leadership is seen as the "most ideal" style; principals with a democratic style are felt to have various advantages for developing schools. A democratic leader can function as a catalyst that can speed up processes naturally and help achieve the object to be achieved in a way that best suits the conditions of the group (Miroj et al., 2020). The democratic leadership style is modernist and participatory; namely, in the implementation of leadership, all members are invited to participate and contribute their thoughts and energy to achieve organizational goals (Saputra et al., 2021). The principal's democratic attitude is seen with a pattern of high obligation attitudes and high tolerance rules (Abowitz \& Kathleen, 2019). Leaders apply a very caring nature in improving the welfare of teachers and employees (Szeto, 2021).

According to Muhassanah (2020), the principal's leadership significantly impacts teachers' performance. Principals who have good leadership can also be seen from their ability to motivate teachers to become more enthusiastic, their ability to stimulate their subordinates, such as: giving equal rights to every teacher, fostering innovation, supporting the way teachers work, involving teacher participation in solving problems and have intelligence/intellectual (Abowitz \& Kathleen, 2019).

To maximize employee performance, we need a leader who can properly manage and direct his subordinates (Tania, 2017). The role of the leader is very influential in creating work effectiveness (Kalangi et al., 2021). Leaders must always motivate their subordinates to work well and effectively. According to Yanti (2021), as part of the form of teacher performance in schools, the democratic leadership style of the principal gives a favorable and significant rise in the educational competency, personality, and professional competence of teachers.

\section{CONCLUSION}

The democratic leadership style of junior high school principals in Bara District, Palopo City, is included in the High category with a sampling frequency of 16 and a percentage of $41 \%$, with a mean score of 64.56. The performance of teachers of SMP/MTs in Bara District, Palopo City, is included in the Medium category with a sampling frequency of 22 and a percentage of $56 \%$, with a mean score of 49.36. The principal's leadership style on the performance of junior high school teachers in the district of Bara, Palopo City, has a significant influence. Based on the results of the research and discussion that have been described in the previous chapter, and the presentation of the results of the data analysis presented, this study concludes that in the partial t-test it is known that the $t$ count value is 2.268 . The $t$ table is 1.995 or $2.268>1.995$, and the significant value of democratic leadership style is $0.029<0.05$ (Ho is rejected and $\mathrm{H} 1$ is accepted). This means that the democratic leadership style has a positive and significant effect on teacher performance. 


\section{REFERENCES}

Abowitz, K., \& Kathleen. (2019). The school principal as democratic leader: a critique of the Wallace Foundation's vision of the principalship. International Journal of Leadership in Education, $o(0), 1-7$. https://doi.org/10.1080/13603124.2019.1637545

Asri, Y. N. (2018). Hubungan Persepsi Mahasiswa pada Kinerja Dosen terhadap Tingkat Kelulusan Mahasiswa. Al-Tanzim: Jurnal Manajemen Pendidikan Islam, 2(2), 129-136.

Bali, M. M. E. I., Muali, C., \& Munawaroh, L. (2020). Self-Efficacy sebagai Media Peningkatan Profesionalisme Guru di Madrasah. Risalah: Jurnal Pendidikan Dan Studi Islam, 6(1), 244257.

Cecilia, R. (2020). Pengaruh Gaya Kepemimpinan Kepala Sekolah Terhadap Kinerja Sekolah di SDN Dengkek 01 Pati. Journal Industrial Engineering \& Management Research (Jiemar), 1(2), 18. Retrieved from http://www.jiemar.org

Cilek, A. (2019). The effect of leadership on organisational commitment: A meta-analysis. Cypriot Journal of Educational Sciences, 14(4), 554-564. https://doi.org/10.18844/cjes.v11i4.4244

Endaryono, B. T., Wasliman, I., Iriantara, Y., \& Sauri, U. S. (2021). Gaya Kepemimpinan Demokratis Kepala SMK DALAM Meningkatkan Mutu Lulusan Berdaya Saing di SMK Bina Mandiri dan SMK Karya Guna 2 Kota Bekasi. Journal of Applied Business and Economics (JABE), 7(3), 357-366.

Everett, M., \& Raven, M. (2018). Measuring Optimal Experiences of CANR Undergraduates in a Leadership Course. Journal of Agricultural Education, 59(1), 35-50. https://doi.org/10.5032/jae.2018.01035

Fathorrazi, A. (2017). Kepemimpinan Kepala Sekolah Dalam Implementasi Dan Pengembangan Kurikulum 2013. Al-Tanzim: Jurnal Manajemen Pendidikan Islam, 1(1), 56-63.

Ghozali, A. L., \& Milansari, U. A. (2015). Kepemimpinan Demokratis Kepala Sekolah di SD Muhammadiyah Program Khusus Andong. 206-208.

Hasibuan, M. (2010). Manajemen Sumber Daya Manusia. Jakarta: Bumi Aksara.

Hefniy, Bali, M. M. E. I., \& Asanah, K. (2020). Leader Member Exchange dalam Membangun Komunikasi Efektif di Pondok Pesantren. El-Buhuth: Borneo Journal of Islamic Studies, 3(1), 77-89.

Herosita, Y. (2017). Implementasi Model Kepemimpinan Demokratis Kepala Sekolah Dalam Meningkatkan Disiplin Guru Mengajar. Jurnal Daya Saing, 3(1), 57-61. https://doi.org/10.35446/dayasaing.v3i1.82

Hersey, P., \& Blanchard, K. H. (1997). Situational Leadership. Dean's Forum, 12(2), 1-8.

Hill-Berry, N. P. (2019). Expanding leadership capacity toward social justice. Research in $\begin{array}{llll}\text { Educational Administration and Leadership, 4(3), } & \text { 720-742. }\end{array}$ https://doi.org/10.30828/real/2019.3.10

Kalangi, S., Weol, W., Tulung, J., \& Rogahang, H. (2021). Principal Leadership Performance: Indonesian Case. The International Journal of Social Sciences World, 3(2), 74-89.

Kheruniah, A. E. (2013). A Teacher Personality Competence Contribution To A Student Study Motivation And Discipline To Fiqh Lesson. International Journal of Scientific \& Technology Research, 2(2), 108-112. Retrieved from https://www.mendeley.com/catalogue/29d54a345a66-30c1-8913-78ddea1e2c9o/

Kholil, M. M., \& Karwanto. (2021). Peran Kepemimpinan Demokrasi Kepala Sekolah dalam Meningkatkan Kinerja Guru. Jurnal Inspirasi Manajemen Pendidikan, 9(1), 87-97.

Khosiah, S., \& Maryani, K. (2020). Pengaruh Gaya Kepemimpinan Demokratis Kepala Sekolah Terhadap Kinerja Guru PAUD. Jurnal Golden Age, 4(1), 20-29.

Kurniawan, A. (2018). Tunjangan Profesi, Pendidikan Dan Latihan Profesi (PLPG) Dalam Kinerja Guru SMA. Jurnal Administrasi Pendidikan, 25(2), 324-335. https://doi.org/10.17509/jap.v25i2.15645

Miroj, A. N., Saputra, B. R., \& Gunawan, I. (2020). Principal Learning Leadership Tips Managing Learning in Schools. Proceedings of the 6th International Conference on Education and Technology (ICET 202O), 501, 85-88. https://doi.org/10.2991/assehr.k.201204.012

Muhassanah, N. (2020). Pengaruh Kepemimpinan Kepala Sekolah Terhadap Kinerja Guru Sekolah Dasar Di Banyumas. Jurnal Utile, 6(1), 66-77.

Munir, H., \& Iqbal, M. Z. (2018). A Study of Relationship between Leadership Styles of Principals and Job Satisfaction of Teachers in Colleges for Women. Bulletin of Education and Research, 
$40(2), 65-78$.

Nadir, M. (2018). Pengaruh Kepemimpinan Demokratis Kepala Sekolah Terhadap Kinerja Guru dan Pegawai pada SMP Negeri 3 Pamboang. Jurnal Pendidikan Pepatudzu, 13(2), 148-162. https://doi.org/10.35329/fkip.v13i2.113

Najemiah, A. (2017). Pengaruh Supervisi Dan Sertifikasi Terhadap Kinerja Guru (Studi Kasus Pada Sekolah Menengah Pertama Negeri 7 Palu). Jurnal Katalogis, 5(6), 10-19.

Nasir, M., Bulu, K., \& Shaleh, M. (2021). Tipe Kepemimpinan Demokratis Kepala Madrasah dalam Meningkatkan Kompetensi Profesional Guru. Kelola: Journal of Islamic Education Management, 6(1), 37-50.

Nasukah, B., Sulistyorini, S., \& Winarti, E. (2020). Peran Komunikasi Efektif Pemimpin Dalam Meningkatkan Kinerja Institusi. AL-TANZIM: Jurnal Manajemen Pendidikan Islam, 4(1), 8193. https://doi.org/10.33650/al-tanzim.v4i1.899

Nurdiansyah, N. M. (2021). Policy and Implementation of Education Management Based on Madrasah. Al-Tanzim: Jurnal Manajemen Pendidikan Islam, 5(1), 14-27.

Purwanto, A., Sopa, A., Primahendra, R., Kusumaningsih, S. W., \& Pramono, R. (2020). Pengaruh Gaya Kepemimpinan Transactional, Transformational, Authentic Dan Authoritarian Terhadap Kinerja Guru Madrasah Tsanawiyah Di Kudus. Al-Tanzim: Jurnal Manajemen Pendidikan Islam, 4(1), 70-80. https://doi.org/10.33650/al-tanzim.v4i1.938

Rahman, A., \& Subiyantoro, S. (2021). The Leardership Role of School Principals in Online Learning During the Covid-19 Pandemic. Al-Tanzim: Jurnal Manajemen Pendidikan Islam, 5(1), 165175. https://doi.org/10.33650/al-tanzim.v5i1.1805

Rahsel, Y. (2017). Kinerja Pegawai Universitas Padjadjaran Bandung: Iklim Kerja Dan Motivasi. Manajemen Magister, 3(1), 107-123.

Rehman, A., Khan, M., \& Waheed, Z. (2019). School Heads' Perceptions About Their Leadership Styles. Journal of Education and Educational Development, 6(1), 138-153. https://doi.org/10.22555/joeed.v6i1.2288

Rohman, F. A., \& Muna, N. (2019). Kepemimpinan Demokratis Kepala Madrasah Ibtidaiyah (MI) Nurul Ummah Kotagede Yogyakarta. MANAGERIA: Jurnal Manajemen Pendidikan Islam, 3(2), 269-288. https://doi.org/10.14421/manageria.2018.32-04

Rosaliawati, B. N., Mustiningsih, M., \& Arifin, I. (2020). Hubungan Gaya Kepemimpinan Kepala Sekolah Dan Kinerja Guru. Jurnal Administrasi Dan Manajemen Pendidikan, 3(1), 61-71. https://doi.org/10.17977/umo27v3i12020p61

Rostiawati, E. (2020). Efektifitas Manajemen Kepemimpinan Dalam Menciptkan Good Governance. Al-Tanzim: Jurnal Manajemen Pendidikan Islam, 4(1), 59-69.

Russamsi, Y., Hadian, H., \& Nurlaeli, A. (2020). Pengaruh Kepemimpinan Kepala Sekolah Dan Peningkatan Profesional Guru Terhadap Kinerja Guru Di Masa Pandemi Covid-19. MANAGERE: Indonesian Journal of Educational Management, 2(3), 244-255. https://doi.org/10.52627/ijeam.v2i3.41

Said, A. (2018). Kepemimpinan Kepala Sekolah Dalam Melestarikan Budaya Mutu Sekolah. Evaluasi, 2(1), 257-273.

Salim, S., \& Hasanah, E. (2021). Principal Leadership in Developing Al-Qur'an Learning Management. Al-Tanzim: Jurnal Manajemen Pendidikan Islam, 5(1), 83-94. https://doi.org/10.33650/al-tanzim.v5i1.1673

Sanjani, M. A. (2018). Kepemimpinan Demoratis Kepala Sekolah. Jurnal Serunai Administrasi Pendidikan, 7(1), 75-83.

Saputra, W., Gistituati, N., \& Padang, U. N. (2021). Kepemimpinan Demokratis Kepala Sekolah di Sekolah Menengah Kejuruan. Edukatif : Jurnal Ilmu Pendidikan, 3(5), 2905-2910.

Suherman. (2014). Strategi pembelajaran Matematika Kontempore,. Bandung: FMIPA Universitas Pendidikan Indonesia.

Szeto, E. (2021). How do principals' practices reflect democratic leadership for inclusion in diverse school settings? A Hong Kong case studyStudy, How do principals' practices reflect democratic leadership for inclusion in diverse school settings? A Hong Kong case studyHo. Educational Management Administration \& Leadership, 49(3), 471-492.

Tania, Y. (2017). Motivasi Kerja terhadap Kinerja Karyawan pada PT Premier Management Consulting. Agora, 5(1), 1-8.

Usman, H. (2011). Manajemen Teori, Praktek dan Riset Pendidikan. Jakarta: PT Bumi Aksara.

Wibowo, A., \& Hasanah, S. N. (2021). Kepemimpinan Perempuan Dalam Menciptakan Sekolah 
Ramah Anak. Quality, 9(1), 87. https://doi.org/10.21043/quality.v9i1.10109

Wirjana, B. R., \& Supardo, S. (2011). Kepemimpinan Dasar-Dasar dan Pengembanganya. Yogyakarta: Andi Offset.

Yanti, F. (2021). Pengaruh Gaya Kepemimpinan Demokratis Kepala Sekolah terhadap Kompetensi Guru. Kelola: Journal of Islamic Education Management, 6(1), 9-24.

Zainuddin, Badrudin, \& Haryanti, E. (2020). Kepemimpinan Transformasional Kepala Pengaruhnya Terhadap Komitmen Organisasi Guru. Managere: Indonesian Journal of Educational, 2(3), 346-353. 